\title{
PBC: Animal Models of Cholangiopathies and Possible Endogenous Viral Infections
}

\author{
Masashi Ninomiya, Yoshiyuki Ueno, and Tooru Shimosegawa \\ Division of Gastroenterology, Department of Gastroenterology, Tohoku University Graduate School of Medicine, \\ Seiryo, Aoba-ku, Sendai 980-8575, Japan \\ Correspondence should be addressed to Yoshiyuki Ueno, yueno@med.tohoku.ac.jp
}

Received 2 April 2011; Accepted 19 June 2011

Academic Editor: A. J. Demetris

Copyright (๑) 2012 Masashi Ninomiya et al. This is an open access article distributed under the Creative Commons Attribution License, which permits unrestricted use, distribution, and reproduction in any medium, provided the original work is properly cited.

\begin{abstract}
Primary Biliary Cirrhosis (PBC) is considered an autoimmune disease characterized by immune-mediated destruction of the intrahepatic bile ducts and its characteristic serologic marker, the anti-mitochondrial antibody (AMA). Several factors were proposed to clarify the pathological and immunological mechanisms of PBC. Immunological reaction with a bacterial or a viral association was identified in the previous report, and it seems probable that $\mathrm{PBC}$ was thought to have such an etiology. The majority of patients with PBC was reported to have both RT-PCR and immunohistochemistry evidence of human betaretrovirus infection in lymph nodes or in 2008, the patient who developed PBC with high HIV viral load had an antiviral therapy and recovered. To understand the etiology of $\mathrm{PBC}$ associated with infection, several factors should be considered and especially animal models may be useful. In this paper, we introduce three typical animal models of PBC: the dominant-negative form of transforming growth factor- $\beta$ receptor type II (dnTGF $\beta$ RII) mouse, IL-2R $\alpha^{-/-}$mouse and NOD.c3c4 mouse, are enumerated and described, and we discuss previous reports of viral infection associated with PBC and consider the etiology of PBC from our analysis of results in NOD.c3c4 mouse.
\end{abstract}

\section{Introduction}

Primary Biliary Cirrhosis (PBC) is considered an autoimmune disease characterized by immune-mediated destruction of the intrahepatic bile ducts and its characteristic serologic marker, the anti-mitochondrial antibody (AMA). AMA is a highly specific autoantibody found in about $90 \%$ of patients with PBC that reacts with an epitope on the E2 subunit of the pyruvate dehydrogenase enzyme complex (PDCE2) [1-3]. The epitopes discerned by anti-PDC-E2 and CD4 and CD8 autoreactive T cells are present in the inner lipoyl domain of PDC-E2. A 100-fold increase in CD4 and a 10-fold increase in CD8 autoreactive T cells infiltrate into the portal tracts $[4,5]$. Moreover, several factors were proposed to clarify the pathological and immunological mechanisms of PBC. Some biological features of the bile duct cells have been reported, suggesting a basis for their distinctive destruction [6-8]. Optionally, soon after autoimmune diseases were first recognized more than a century ago, immunological reaction with a bacterial or a viral association was identified and PBC was thought to have such an etiology (Table 1). [911]. The majority of patients with $\mathrm{PBC}$ were reported to have both RT-PCR and immunohistochemistry evidence of human betaretrovirus infection in lymph nodes [12], or in 2008, the patient who developed PBC with high HIV viral load had an antiviral therapy and recovered [13]. To determine whether PBC can be induced by infections, first autoimmunity needs to be defined. Autoimmune diseases occur when a response to a self-antigen involving $\mathrm{T}$ cells, B cells, or autoantibodies induces injury systemically or against a specific organ [14]. Although an autoimmune response occurs in most persons, it is only in a few persons that disease actually appears. In PBC, how can infection induce autoimmunity? The mechanism to explain the association of infection is molecular mimicry of autoepitops by peptides of microorganisms. This results in cryptic T-cell epitopes, the degeneracy of T-cell receptors, and the disruption of immune tolerance $[15,16]$. This is of great significance for 
TABLE 1: Viral infections in humans associated with autoimmune diseases.

\begin{tabular}{ll}
\hline $\begin{array}{l}\text { Relevance or suspicion of } \\
\text { autoimmune human diseases }\end{array}$ & Representative viruses \\
\hline PBC & HIV-1 p24 \\
& MMTV \\
Eultiple sclerosis & $\begin{array}{l}\text { Epstein-Barr virus (EBV) Measles } \\
\text { virus } \\
\text { Coxsackie virus B4 }\end{array}$ \\
Type1 diabetes & $\begin{array}{l}\text { Cubella virus } \\
\text { Cytomegalovirus (CMV) Mumps } \\
\text { virus }\end{array}$ \\
Rheumatoid arthritis & EBV \\
Systemic lupus erythematosus & EBV \\
Myocarditis & Coxsackievirus B3 \\
& CMV \\
Myasthenia gravis & Herpes simplex virus \\
Guillain-Barre syndrome & HCV \\
& CMV \\
\hline
\end{tabular}

PBC because of the tendency of several viruses to target particularly the liver. There are several mechanisms by which viruses are thought to induce an autoimmune response. These include the expression of some autoantigens, the expression of major histocompatibility complex molecules, and changes in cytokine production [16]. To understand the etiology of $\mathrm{PBC}$ associated with infection, several factors should be considered and especially animal models may be useful $[14,17]$. The association of betaretroviral protein production and aberrant PDC-E2-like protein expression in the IL-2R $\alpha^{-/-}$mouse and Nonobese diabetic (NOD).c3c4 mouse was reported recently [18].

In this paper, we introduce three typical animal models of PBC: the dominant-negative form of transforming growth factor- $\beta$ receptor type II ( $\operatorname{dnTGF} \beta \mathrm{RII})$ mouse, IL-2R $\alpha^{-/-}$ mouse, and NOD.c3c4 mouse are enumerated and described [19-21]. Additionally, we discuss previous reports of viral infection associated with $\mathrm{PBC}$ and consider the etiology of $\mathrm{PBC}$ from our analysis of results in NOD.c3c4 mouse.

\section{Murine Model of PBC}

2.1. DnTGF $\beta$ RII Mouse. TGF- $\beta$ is the most widely distributed cytokine with pleiotropic effects on cell growth and immunological controls, specifically having a promoting effect on the development of the regulatory T-cell compartment [22]. dnTGF $\beta$ RII mice were originally developed by Gorelik and Flavell for the purpose of analyzing the role of this receptor, which regulates the activation of the $\mathrm{T}$ cell function [23]. To disrupt the intracellular domain of the normal receptor in this mouse, the receptor is incompetent of transduction after TGF- $\beta$ ligation. The expression of $\operatorname{dnTGF} \beta$ RII is limited by the CD4 promotor which lacks CD8 silencer, and this transgenic mouse spontaneously develops features characteristic of $\mathrm{PBC}$ [23]. These features include the expression of AMA with specificity against PDC-E2, BCOADC-E2, and OGDC-E2, as in human PBC. Pathologically, the infiltration of lymphoid cells, especially $\mathrm{CD} 4^{+}$and $\mathrm{CD} 8^{+}$lymphocytes, in the portal tracts causes biliary duct destruction [19] and the accumulation of natural killer T cells (NKT) in the intrahepatic bile duct lesions, resembling the condition found in human PBC [24]. Although the granuloma formations around the portal tracts seen in human $\mathrm{PBC}$ are not present, some lymphocytic aggregations like immature granuloma formation could be observed [25]. Furthermore, the serum levels of cytokines such as IFN- $\gamma$,TNF- $\alpha$,IL-12p 40 , and IL-6 are significantly increased, as seen in human PBC $[26,27]$.

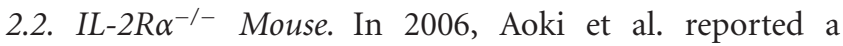
male child with a genetic deficiency of IL-2 receptor $\alpha \mathrm{IL}$ $2 \mathrm{R} \alpha$, $\mathrm{CD} 25$ ) expression who had liver dysfunction with serological expression of PBC. Histologically, there was lymphoid infiltration in the portal tracts and serum antibody to PDCE2. The deficiency of $\mathrm{CD} 4^{+} \mathrm{CD} 25^{+}$subset of regulatory $\mathrm{T}$ cells was considered a key to elucidating of this clinical condition [20]. Based on these findings, Wakabayashi et al. established IL-2R $\alpha^{-/-}$mice and evaluated their hepatic immunopathology [28]. These mice also show AMA positivity against PDC-E2 that localizes to the inner lipoyl domain of the autoantigen. Lymphoid cells, composed of $\mathrm{CD} 4^{+}$and $\mathrm{CD}^{+}$lymphocytes, infiltrate into portal tracts without a significant increase in NKT. Although mild interface hepatitis and biliary duct destruction are seen in the liver, granuloma formations around the portal tracts are not observed [28]. The circulating cytokine profiles are similar to those of dnTGF $\beta$ RII mice, showing elevations of IFN- $\gamma$, TNF- $\alpha$, IL$12 \mathrm{p} 40$, and IL-6, as identified in the serum of patients with PBC $[26,27,29]$.

2.3. NOD.c3c4 Mouse. NOD.c3c4 mice were generated by the introgression of large genetic intervals on chromosome 3 and 4 into a NOD background [21,30]. NOD and genetically modified NOD mice have been reported to progress to not only spontaneous autoimmune diabetes but also rheumatoid arthritis, Sjogren's syndrome, and thyroiditis [31-34]. NOD.c3c4 mice derived from NOD strains are considered to be an animal model of PBC with autoimmune biliary destruction [21,30]. Most importantly, these mice show antibodies to PDC-E2. They express AMA positivity, unlike the dnTGF $\beta$ RII mice and IL- $2 \mathrm{R} \alpha^{-/-}$mice, and the rate of positivity has reached 50-60\% [35]. Portal tract infiltration with $\mathrm{CD}^{+}, \mathrm{CD}^{+}$, and $\mathrm{CD} 8^{+}$lymphocytes results in chronic nonsuppurative destructive cholangitis and epithelioid granuloma formations [21,30]. However, the morphological features of the bile ducts lesions differ from those in human PBC, in which characteristic biliary cyst formations as well as apparent hepatomegaly are described [36]. 
TABLE 2: Antiviral trials for PBC.

\begin{tabular}{|c|c|c|c|c|c|c|}
\hline Trial & Method & Subject & Design & Primary outcome & Year & Reference \\
\hline $\begin{array}{l}\text { Pilot studies of single and } \\
\text { combination antiretroviral } \\
\text { therapy }\end{array}$ & $\begin{array}{l}\text { Lamivudine }+ \text { Zidovu- } \\
\text { dine versus Lamivudine }\end{array}$ & Human & $\begin{array}{l}\text { Randomized } \\
\text { controlled } \\
\text { trial (RCT) }\end{array}$ & $\begin{array}{l}\text { Serological improvements } \\
\text { of alkaline phos-phatase, } \\
\text { AST and ALT. Histological } \\
\text { improvement in } \\
\text { necroinflammatory score } \\
\text { and a reduction in bile } \\
\text { duct injury. }\end{array}$ & 2004 & {$[43]$} \\
\hline $\begin{array}{l}\text { Clinical trial: randomized } \\
\text { controlled trial of lamivudine } \\
\text { and zidovudine (Combivir) }\end{array}$ & $\begin{array}{l}\text { Lamivudine + Zidovu- } \\
\text { dine + UDCA versus } \\
\text { UDCA }\end{array}$ & Human & RCT & $\begin{array}{l}\text { Serological improvements } \\
\text { in serial alkaline } \\
\text { phosphatase, ALT and } \\
\text { AST. }\end{array}$ & 2008 & {$[44]$} \\
\hline $\begin{array}{l}\text { Randomized controlled trial of } \\
\text { lamivudine }\end{array}$ & Lamivudine versus UDCA & Human & RCT & $\begin{array}{l}\text { One case showed a } \\
\text { decrease of AMA titers. }\end{array}$ & 2010 & {$[45]$} \\
\hline $\begin{array}{l}\text { Combination antiretroviral } \\
\text { therapy with Combivir }\end{array}$ & $\begin{array}{l}\text { Lamivudine }+ \text { Zidovu- } \\
\text { dine versus Placebo }\end{array}$ & $\begin{array}{l}\text { NOD.c3c4 } \\
\text { mouse }\end{array}$ & & $\begin{array}{l}\text { Histological improvement } \\
\text { in necroinflammatory } \\
\text { score and a reduction in } \\
\text { bile duct injury. No } \\
\text { improvement on bile duct } \\
\text { cyst. Decrease in viral } \\
\text { burden. }\end{array}$ & 2007 & {$[46]$} \\
\hline $\begin{array}{l}\text { Highly active antiretroviral } \\
\text { therapy with reverse trans- } \\
\text { criptase inhibitors and protease } \\
\text { inhibitor }\end{array}$ & $\begin{array}{l}\text { Combination of reverse } \\
\text { transcriptase and protease } \\
\text { inhibitor }\end{array}$ & $\begin{array}{l}\text { NOD.c3c4 } \\
\text { mouse }\end{array}$ & & $\begin{array}{l}\text { Serological improvements } \\
\text { in alkaline phos-phatase } \\
\text { and AST. Complete } \\
\text { disappearance of } \\
\text { cholangitis. }\end{array}$ & 2008 & {$[47]$} \\
\hline
\end{tabular}

\section{Possibility of Viral Infection Associated with PBC}

It has been thought that some viruses may associate with human diseases of oncogenesis or autoimmunity because of their genome integration or specific viral-encoding proteins. Especially, in 1998, Munoz et al. described that there was an antibody for human immunodeficiency virus-1 (HIV1) in the serum of PBC patients [37]. To investigate for a possible immune response to the p24 gag protein of HIV1 , moderate-to-strong reactivity was found in about $30 \%$ of the patients with Sjogren's syndrome, as compared with less than $1 \%$ of healthy controls [38], and the $36 \%$ of systemic lupus erythematosus (SLE) patients produced antibodies to the p24 gag protein [39]. Mason et al. discovered HIV-1 p24 gag protein seroreactivity in $35 \%$ of patients with PBC, $29 \%$ of patients with SLE, and 39\% of patients with either primary sclerosing cholangitis or biliary atresia, compared with only $4 \%$ of patients with alcohol-related liver disease or alpha1-antitrypsin-deficiency liver disease, and only $4 \%$ of healthy volunteers. Moreover, Western blot reactivity to the human intracisternal A-type particle (HIAP) proteins related to HIV-1 was found in $51 \%$ of patients with PBC, in $58 \%$ patients with SLE, and in $17 \%$ of those with other biliary diseases. None of the 23 patients with either alcohol-related liver disease or alpha1-antitrypsin deficiency and only one of the healthy controls showed the same reactivity to HIAP proteins [40]. Therefore, these antibody reactivities found in patients with $\mathrm{PBC}$ may be attributable to an immune response to uncharacterized viral proteins that share antigenic determinants with HIV-1-related retroviruses.

In 2003, a human betaretrovirus clone sequence was originally detected from the biliary epithelium cDNA library of a patient with PBC. When searching viral data registered in BLASTN, the initial partial pol gene fragment was found to exhibit $95 \%$ to $97 \%$ identities with mouse mammary tumor virus (MMTV) and with retrovirus sequences derived from human breast cancer samples within the overlapping sequence $[12,41]$. Using a specific MMTV antibody, viral proteins were shown in the perihepatic lymph nodes but not in liver tissue samples from patients with PBC [41]. However, Selmi et al. expressed an opposing view concerning this result [42].

Some pilot studies were conducted to determine whether antiviral therapy impacted the disease progression (Table 2). First, Mason et al. performed a trial with reverse-transcriptase inhibitors (lamivudine group versus lamivudine/zidovudine group) for patients with PBC. The lamivudine/zidovudine group showed significant serological improvement in the activities of alkaline phosphatase, AST and ALT, and histological assessment revealed an improvement in the necroinflammatory score and a reduction in bile duct injury compared to the lamivudine group [43]. A further clinical trial was performed with a combination of lamivudine and zidovudine versus ursodeoxycholic acid (UDCA). Significant differences were observed in the antiviral therapy versus UDCA with serological improvements in serial alkaline phosphatase, ALT and AST as well as the clinical score [44]. Thus, reverse-transcriptase inhibitors are 
expected to suppress retroviral proliferation and contribute to the improvement of $\mathrm{PBC}$. We once investigated the efficacies of 90 day's administration of lamivudine to 20 PBC patients with unsatisfactory biochemical responses to UDCA in a randomized double blind control trial. As a result, no significant biochemical difference was seen between both groups. However, of interest, one case showed a decrease of AMA titers and biochemical response [45]. These results were similar to those of studies conducted by Mason et al. [43]; yet the true efficacy should be evaluated in large-scale control trials.

\section{Are NOD.c3c4 Mice Infected with a Retrovirus?}

NOD.c3c4 mice have been described as a mouse model with several features similar to PBC [30]. However, these mice develop marked biliary cyst formation that is not shown in human PBC. In human PBC, the destruction of cholangiocytes leads to ductpenia [48]. When we analyzed the gene expression of the cholangiocytes of such mice using microarray analysis, there was consistent liver-specific downregulation in the expression of Fas antigen (CD95) [36]. Fas (CD95) antigen is a member of the tumor necrosis factor family that binds to Fas ligand (FasL). This gene is situated at chromosome 19 in mouse [49]. Fas/FasL interactions play an important role in apoptosis [49-51]. Fas is detected in hepatocytes and plays an important role in inflammation and cell death in hepatitis virus-infected liver [52]. The Fas system on cholangiocytes has been also reported in human and rats, and enhanced expression of FasL on cholangiocytes has been implicated in progressive bile duct loss in PBC through apoptosis [53]. Furthermore, FasL expressed by cholangiocarcinomas was reported to induce lymphocyte cell death and escape immune surveillance [54]. It has been reported that the Fas/FasL system is strongly associated with biliary pathological conditions. It was thought that, because of the downregulation of Fas antigen, the apoptosis of cholangiocytes cannot easily occur and therefore biliary cyst formation was found in NOD.c3c4 mice [36]. However, it was considered that there are also other factors because the degree of the cyst formation differed according to the individual though the genetic expression was the same.

In 2007, Chen et al. reported that MMTV gag and pol gene expression was 4 - to 25 -fold higher in all three autoimmune biliary disease models, NOD.c3c4, dnTGF$\beta \mathrm{RII}$, and IL-2R $\alpha^{-/-}$, as compared to control mice when using real-time RT-PCR to quantify MMTV using gag and pol primers [55]. A randomized study was conducted using NOD.c3c4 mice treated with a combination therapy of lamivudine and zidovudine or with placebo (Table 2). Serial hepatic biochemistry studies showed diminished alkaline phosphatase in the mice treated with combination therapy. Histological evaluation showed a significant decrease in the necroinflammatory score and the grade of the bile duct injury in the combination therapy group. However, therapy had little improvement on bile duct cyst formation. When compared to mice receiving placebo group, combination therapy group reduced viral burden measured by the pol and gag gene RT-PCR [46]. Moreover, Graham et al. treated NOD.c3c4 mice with combination of reverse transcriptase inhibitors and protease inhibitor. Hepatic biochemistry showed significant improvements in alkaline phosphatase and AST, and the cholangitis completely disappeared [47]. Thus, the detection of MMTV in the NOD.c3c4 mice and resolution of biliary disease with antiviral therapy supports the retroviral hypothesis for PBC.

However, in order to prove that viral factors are involved in the pathogenesis of PBC, it is necessary to understand and elucidate the mechanism of viral replication, reproduction, the transcription of the virus genomes, the pathogenic roles of viral tropics, the integrated state, and the interaction with the host's immune system, especially the mechanism by which autoimmune tolerance is broken. Therefore, it is premature to relate the cause of the clinical condition of $\mathrm{PBC}$ to viral infection based only on the present report. However, given the unprecedented progress of biotechnology, a more detailed understanding of these issues can be expected in the near future.

\section{References}

[1] Y. Nakanuma and G. Ohta, "Histometric and serial section observations of the intrahepatic bile ducts in primary biliary cirrhosis," Gastroenterology, vol. 76, no. 6, pp. 1326-1332, 1979.

[2] M. E. Gershwin, I. R. Mackay, A. Sturgess, and R. L. Coppel, "Identification and specificity of a cDNA encoding the 70 $\mathrm{KD}$ mitochondrial antigen recognized in primary biliary cirrhosis," Journal of Immunology, vol. 138, no. 10, pp. 35253531, 1987.

[3] R. L. Coppel, L. J. McNeilage, C. D. Surh et al., "Primary structure of the human M2 mitochondrial autoantigen of primary biliary cirrhosis: dihydrolipoamide acetyltransferase," Proceedings of the National Academy of Sciences of the United States of America, vol. 85, no. 19, pp. 7317-7321, 1988.

[4] J. van de Water, A. A. Ansari, C. D. Surh et al., "Evidence for the targeting by 2-oxo-dehydrogenase enzymes in the $\mathrm{T}$ cell response of primary biliary cirrhosis," Journal of Immunology, vol. 146, no. 1, pp. 89-94, 1991.

[5] D. E. J. Jones, J. M. Palmer, O. F. W. James, S. J. Yeaman, M. F. Bassendine, and A. G. Diamond, "T-cell responses to the components of pyruvate dehydrogenase complex in primary biliary cirrhosis," Hepatology, vol. 21, no. 4, pp. 995-1002, 1995.

[6] K. Harada, S. Ozaki, M. E. Gershwin, and Y. Nakanuma, "Enhanced apoptosis relates to bile duct loss in primary biliary cirrhosis," Hepatology, vol. 26, no. 6, pp. 1399-1405, 1997.

[7] J. A. Odin, R. C. Huebert, L. Casciola-Rosen, N. F. LaRusso, and A. Rosen, "Bcl-2-dependent oxidation of pyruvate dehydrogenase-E2, a primary biliary cirrhosis autoantigen, during apoptosis," Journal of Clinical Investigation, vol. 108, no. 2, pp. 223-232, 2001.

[8] A. Tanaka, P. S. C. Leung, T. P. Kenny et al., "Genomic analysis of differentially expressed genes in liver and biliary epithelial cells of patients with primary biliary cirrhosis," Journal of Autoimmunity, vol. 17, no. 1, pp. 89-98, 2001.

[9] S. P. M. Fussey, S. T. Ali, J. R. Guest, O. F. W. James, M. F. Bassendine, and S. J. Yeaman, "Reactivity of primary biliary 
cirrhosis sera Escherichia coli dihydrolipoamide acetyltransferase (E2p): characterization of the main immunogenic region," Proceedings of the National Academy of Sciences of the United States of America, vol. 87, no. 10, pp. 3987-3991, 1990.

[10] S. A. Long, C. Quan, J. van de Water et al., "Immunoreactivity of organic mimeotopes of the E2 component of pyruvate dehydrogenase: connecting xenobiotics with primary biliary cirrhosis," Journal of Immunology, vol. 167, no. 5, pp. 29562963, 2001.

[11] P. S. C. Leung, C. Quan, O. Park et al., "Immunization with a xenobiotic 6-bromohexanoate bovine serum albumin conjugate induces antimitochondrial antibodies," Journal of Immunology, vol. 170, no. 10, pp. 5326-5332, 2003.

[12] L. Xu, Z. Shen, L. Guo et al., "Does a betaretrovirus infection trigger primary biliary cirrhosis?" Proceedings of the National Academy of Sciences of the United States of America, vol. 100, no. 14, pp. 8454-8459, 2003.

[13] G. Schembri and P. Schober, "Killing two birds with one stone," The Lancet, vol. 377, no. 9759, p. 96, 2011.

[14] N. R. Rose, "Mechanisms of autoimmunity," Seminars in Liver Disease, vol. 22, no. 4, pp. 387-394, 2002.

[15] S. Shimoda, M. Nakamura, H. Ishibashi, K. Hayashida, and Y. Niho, "HLA DRB4 0101-restricted immunodominant T cell autoepitope of pyruvate dehydrogenase complex in primary biliary cirrhosis: evidence of molecular mimicry in human autoimmune diseases," Journal of Experimental Medicine, vol. 181, no. 5, pp. 1835-1845, 1995.

[16] J. van de Water, H. Ishibashi, R. L. Coppel, and M. E. Gershwin, "Molecular mimicry and primary biliary cirrhosis: premises not promises," Hepatology, vol. 33, no. 4, pp. 771$775,2001$.

[17] M. Regner and P. H. Lambert, "Autoimmunity through infection or immunization?" Nature immunology, vol. 2, no. 3, pp. 185-188, 2001.

[18] G. Zhang, M. Chen, D. Graham et al., "Mouse mammary tumor virus in anti-mitochondrial antibody producing mouse models," Journal of Hepatology. In press.

[19] S. Oertelt, Z. X. Lian, C. M. Cheng et al., "Anti-mitochondrial antibodies and primary biliary cirrhosis in TGF- $\beta$ receptor II dominant-negative mice," Journal of Immunology, vol. 177, no. 3, pp. 1655-1660, 2006.

[20] C. A. Aoki, C. M. Roifman, Z. X. Lian et al., "IL-2 receptor alpha deficiency and features of primary biliary cirrhosis," Journal of Autoimmunity, vol. 27, no. 1, pp. 50-53, 2006.

[21] S. Koarada, Y. Wu, N. Fertig et al., "Genetic control of autoimmunity: protection from diabetes, but spontaneous autoimmune biliary disease in a nonobese diabetic congenic strain," Journal of Immunology, vol. 173, no. 4, pp. 2315-2323, 2004.

[22] J. Massague, “TGF-beta signal transduction," Annual Review of Biochemistry, vol. 67, pp. 753-791, 1998.

[23] L. Gorelik and R. A. Flavell, "Abrogation of TGF $\beta$ signaling in $\mathrm{T}$ cells leads to spontaneous $\mathrm{T}$ cell differentiation and autoimmune disease," Immunity, vol. 12, no. 2, pp. 171-181, 2000.

[24] K. Harada, K. Isse, K. Tsuneyama, H. Ohta, and Y. Nakanuma, "Accumulating $\mathrm{CD} 57^{+} \mathrm{CD}^{+}$natural killer T cells are related to intrahepatic bile duct lesions in primary biliary cirrhosis," Liver International, vol. 23, no. 2, pp. 94-100, 2003.

[25] S. Oertelt, W. M. Ridgway, A. A. Ansari, R. L. Coppel, and M. E. Gershwin, "Murine models of primary biliary cirrhosis: comparisons and contrasts," Hepatology Research, vol. 37, no. 3, pp. S365-S369, 2007.

[26] M. Shindo, G. E. Mullin, L. Braun-Elwert, N. V. Bergasa, E. A. Jones, and S. P. James, "Cytokine mRNA expression in the liver of patients with primary biliary cirrhosis (PBC) and chronic hepatitis B (CHB)," Clinical and Experimental Immunology, vol. 105, no. 2, pp. 254-259, 1996.

[27] M. Yasoshima, N. Kono, H. Sugawara, K. Katayanagi, K. Harada, and Y. Nakanuma, "Increased expression of inter-leukin-6 and tumor necrosis factor- $\alpha$ in pathologic biliary epithelial cells: in situ and culture study," Laboratory Investigation, vol. 78, no. 1, pp. 89-100, 1998.

[28] K. Wakabayashi, Z. X. Lian, Y. Moritoki et al., "IL-2 receptor $\alpha^{-/-}$mice and the development of primary biliary cirrhosis," Hepatology, vol. 44, no. 5, pp. 1240-1249, 2006.

[29] P. A. Berg, R. Klein, and M. Röcken, "Cytokines in primary biliary cirrhosis," Seminars in Liver Disease, vol. 17, no. 2, pp. 115-123, 1997.

[30] J. Irie, Y. Wu, L. S. Wicker et al., "NOD.c3c4 congenic mice develop autoimmune biliary disease that serologically and pathogenetically models human primary biliary cirrhosis," Journal of Experimental Medicine, vol. 203, no. 5, pp. 12091219, 2006.

[31] P. Humbert and J. L. Dupond, "Multiple autoimmune syndromes (MAS)," Annales de Medecine Interne, vol. 139, no. 3, pp. $159-168,1988$.

[32] K. O. Gtc, C. C. Szeto, V. Yeung, C. C. Chow, H. Chan, and C. S. Cockram, "Autoimmune polyglandular syndrome and primary biliary cirrhosis," British Journal of Clinical Practice, vol. 50, no. 6, pp. 344-346, 1996.

[33] J. P. Lin, J. M. Cash, S. Z. Doyle et al., "Familial clustering of rheumatoid arthritis with other autoimmune diseases," Human Genetics, vol. 103, no. 4, pp. 475-482, 1998.

[34] M. M. Griffiths, J. A. Encinas, E. F. Remmers, V. K. Kuchroo, and R. L. Wilder, "Mapping autoimmunity genes," Current Opinion in Immunology, vol. 11, no. 6, pp. 689-700, 1999.

[35] Y. Ueno, Y. Moritoki, T. Shimosegawa, and M. E. Gershwin, "Primary biliary cirrhosis: what we know and what we want to know about human PBC and spontaneous PBC mouse models," Journal of Gastroenterology, vol. 42, no. 3, pp. 189-195, 2007.

[36] Y. Nakagome, Y. Ueno, T. Kogure et al., "Autoimmune cholangitis in NOD.c3c4 mice is associated with cholangiocyte-specific Fas antigen deficiency," Journal of Autoimmunity, vol. 29, no. 1, pp. 20-29, 2007.

[37] S. Munoz, S. Ballas, R. Norberg, and W. Maddrey, "Antibodies to human immunodeficiency virus (HIV) in primary biliary cirrhosis," Gastroenterology, vol. 94, p. A574, 1988.

[38] N. Talal, M. J. Dauphinee, H. Dang, S. S. Alexander, D. J. Hart, and R. F. Garry, "Detection of serum antibodies to retroviral proteins in patients with primary Sjogren's syndrome (autoimmune exocrinopathy)," Arthritis and Rheumatism, vol. 33, no. 6, pp. 774-781, 1990.

[39] N. Talal, R. F. Garry, P. H. Schur et al., "A conserved idiotype and antibodies to retroviral proteins in systemic lupus erythematosus," Journal of Clinical Investigation, vol. 85, no. 6, pp. 1866-1871, 1990.

[40] A. L. Mason, L. Xu, L. Guo et al., "Detection of retroviral antibodies in primary biliary cirrhosis and other idiopathic biliary disorders," The Lancet, vol. 351, no. 9116, pp. 16201624, 1998.

[41] L. Xu, M. Sakalian, Z. Shen, G. Loss, J. Neuberger, and A. Mason, "Cloning the human betaretrovirus proviral genome from patients with primary biliary cirrhosis," Hepatology, vol. 39, no. 1, pp. 151-156, 2004.

[42] C. Selmi, S. R. Ross, A. A. Ansari et al., "Lack of immunological or molecular evidence for a role of mouse mammary tumor 
retrovirus in primary biliary cirrhosis," Gastroenterology, vol. 127, no. 2, pp. 493-501, 2004.

[43] A. L. Mason, G. H. Farr, L. Xu, S. G. Hubscher, and J. M. Neuberger, "Pilot studies of single and combination antiretroviral therapy in patients with primary biliary cirrhosis," American Journal of Gastroenterology, vol. 99, no. 12, pp. 2348-2355, 2004.

[44] A. L. Mason, K. D. Lindor, B. R. Bacon, C. Vincent, J. M. Neuberger, and S. T. Wasilenko, "Clinical trial: randomized controlled study of zidovudine and lamivudine for patients with primary biliary cirrhosis stabilized on ursodiol," Alimentary Pharmacology and Therapeutics, vol. 28, no. 7, pp. 886894, 2008.

[45] K. Fukushima, Y. Ueno, and T. Shimosegawa, "Treatment of primary biliary cirrhosis: a new challenge?" Hepatology Research, vol. 40, no. 1, pp. 61-68, 2010.

[46] M. Chen, D. Graham, S. Girgis et al., "Combination antiretroviral therapy with Combivir attenuates autoimmune biliary disease in the NOD.c3c4 mouse model of primary biliary cirrhosis," Hepatology, vol. 46, supplement 1, p. 548A, 2007.

[47] D. Graham, M. Chen, S. Girgis, G. Zhang, and A. Mason, "Highly active anti-retroviral therapy completely abrogates cholangitis in the NOD.c3c4 mouse model of PBC," Journal of Hepatology, vol. 2, p. s54, 2008.

[48] G. R. Locke III, T. M. Therneau, J. Ludwig, E. R. Dickson, and K. D. Lindor, "Time course of histological progression in primary biliary cirrhosis," Hepatology, vol. 23, no. 1, pp. $52-$ 56, 1996.

[49] S. Nagata and P. Golstein, "The Fas death factor," Science, vol. 267, no. 5203, pp. 1449-1456, 1995.

[50] T. Sakai, Y. Kimura, K. Inagaki-Ohara, K. Kusugami, D. H. Lynch, and Y. Yoshikai, "Fas-mediated cytotoxicity by intestinal intraepithelial lymphocytes during acute graft-versus-host disease in mice," Gastroenterology, vol. 113, no. 1, pp. 168-174, 1997.

[51] Y. Ueno, M. Ishii, K. Yahagi et al., "Fas-mediated cholangiopathy in the murine model of graft versus host disease," Hepatology, vol. 31, no. 4, pp. 966-974, 2000.

[52] N. Hiramatsu, N. Hayashi, K. Katayama et al., "Immunohistochemical detection of Fas antigen in liver tissue of patients with chronic hepatitis C," Hepatology, vol. 19, no. 6, pp. 13541359, 1994.

[53] M. Iwata, K. Harada, K. Hiramatsu et al., "Fas ligand expressing mononuclear cells around intrahepatic bile ducts co-express CD68 in primary biliary cirrhosis," Liver, vol. 20, no. 2, pp. 129-135, 2000.

[54] F. G. Que, V. A. Phan, V. H. Phan et al., "Cholangiocarcinomas express Fas ligand and disable the Fas receptor," Hepatology, vol. 30, no. 6, pp. 1398-1404, 1999.

[55] M. Chen, D. Graham, G. Zhang et al., "Biliary infection with mouse mammary tumor virus in the NOD.c3c4 mouse and other mouse models of primary biliary cirrhosis," Hepatology, vol. 46, supplement 1, p. 551A, 2007. 


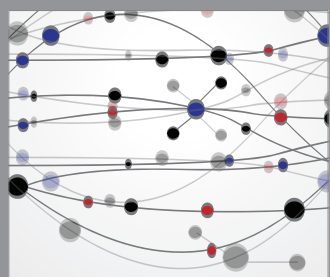

The Scientific World Journal
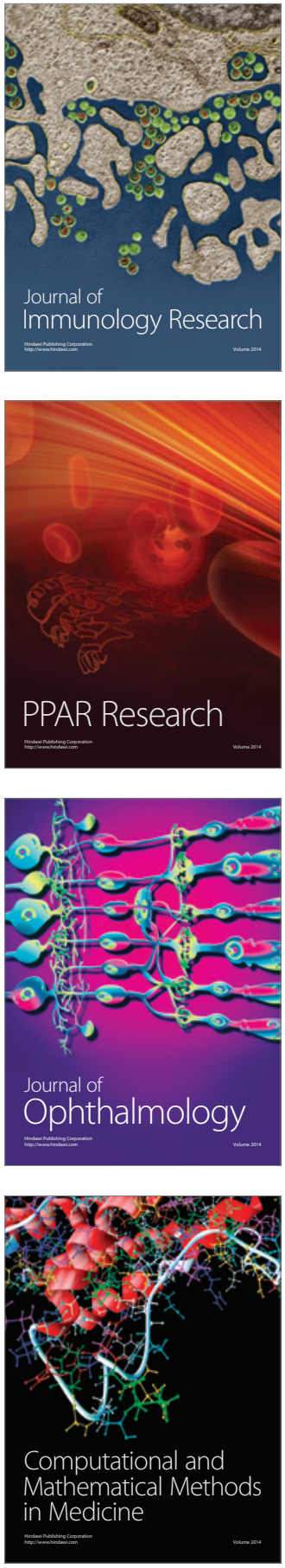

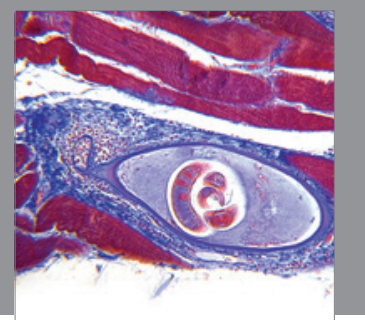

Gastroenterology

Research and Practice
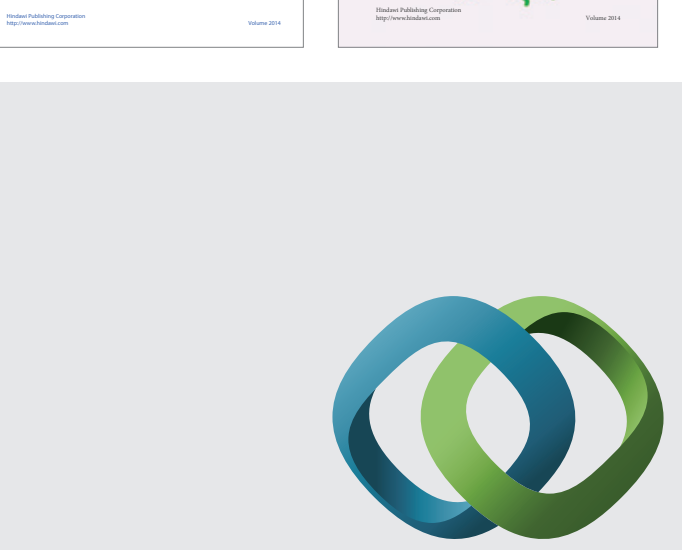

\section{Hindawi}

Submit your manuscripts at

http://www.hindawi.com
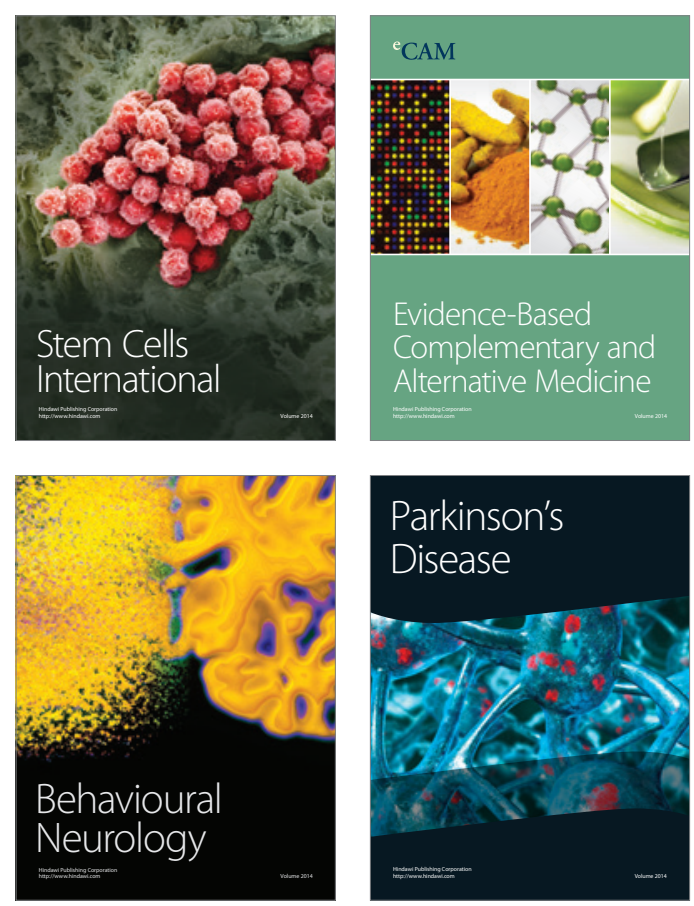

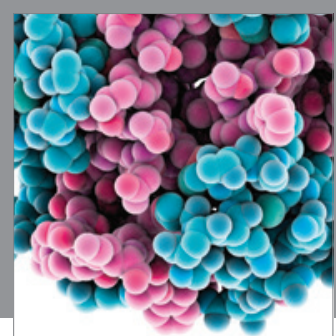

Journal of
Diabetes Research

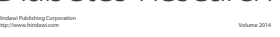

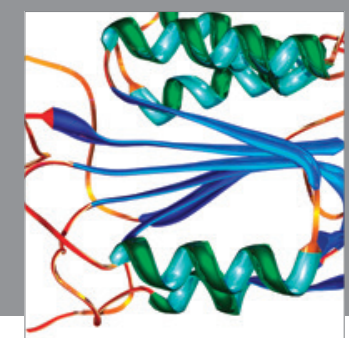

Disease Markers
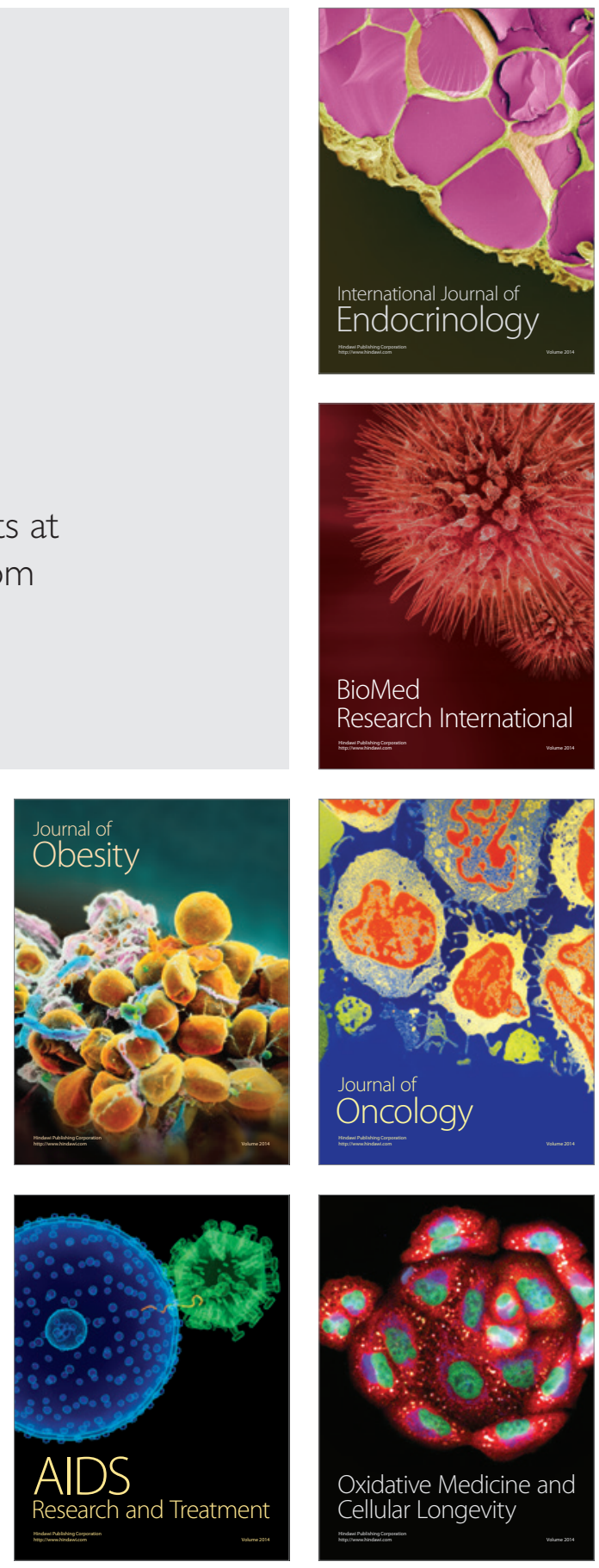